\title{
LA Grade B
}

National Cancer Institute

\section{Source}

National Cancer Institute. LA Grade B. NCI Thesaurus. Code C62425.

One or more mucosal breaks more than $5 \mathrm{~mm}$ long, none of which extends between the tops of two mucosal folds. 